\title{
宇宙線測定用超電導電磁石の設計
}

\author{
島本進* \\ *電気、試験所・機器部超電導研究室 \\ (サックレー原子力研究所滞在)
}

(1970年6月27日)

\section{The Design of a Air-borne Superconducting Magnet \\ for Cosmic Ray Measurement}

\section{Susumu Shimamoto}

Electrotechnical Laboratory, Tokyo, Japan

(On stay at Centre d'Etude Nucleaire de Saciay)

(Received June 27, 1970)

The design process of a air-borne superconducting magnet for cosmic ray measurement is presented. The weight of all this magnet system must be less than $300 \mathrm{~kg}$ and the magnetic field is $20 \mathrm{kG}$ with enough accesses for cosmic ray and for optical system.

The superconducting magnet must work during 12 hours with persistent current mode. The construction of this magnet system is possible with a helium tank of $80 l$, utililzing the aluminum stabilized superconducting wire or the multiple filamentary superconducting wire.

\section{1. まえがき}

放電箱 (spark chamher)，セレンコフ・カウンタ - (Cerenkov counter) 等とともに気球で超電導電 磁石をもちあげ，各種の宇宙線の運動量或はエネルギ 一を測定することが可能である。すでにカリフォルニ ア大学1 ${ }^{1}$ でこの種の超電導電磁石の製作, 動作に成功 している。本目的の超電導電磁石は, 強磁界を必要と すること，上空で使用のため軽量であること，永久電 流で使用されること，へリウムの長時間接続等超電導 電磁石の特性を著しく要求されるので，その設計から みて大変興味深いものである。また，宇宙技術の進歩 とともに，宇宙ステーション内に大きな超電導電磁石 を設置し，宇宙線の測定が可能になることからみても 興味深、。筆者等はサックレー原子力研究所内の宇宙 線測定を行っているグループより，設計，製作の依頼 をうけ，設計案をまとめたので報告する。

\section{2. 使 用条件}

本電磁石は次に列記する使用条件を要する。 (1)使用磁界は約 $20 \mathrm{kG}$ あるいはそれ以上で，上空で磁 界を零にできること。電流を変化することはおこなわ ない。

(2)磁界の均一性はきびしくなく, 三桁の精度で軸成分 $\mathrm{Bz}$ の磁界が解っていれば良い。

(3)磁界の中心にたいし，50度〜80度の角度を持った宇 宙線の入口を要する。

(4)永久電流状態で，地上からのへリウムの補給なしに 10〜12時間一定磁界を保てること。

(5)電磁石本体, 巻枠, クライオスタット, 液体ヘリウ ム等全体で $300 \mathrm{~kg}$ をこえないこと。

(6)放電箱の大きさは, 巾 $24 \mathrm{~cm}$, 高さ $24 \mathrm{~cm}$, 奥行 22 $\mathrm{cm}$ である。

(7)粒子の軌道を光学系統で写すため, 充分な空間が必 要である。 
(8)地上落下の時, 気球全体は最大 $4.5 \mathrm{~m} / \mathrm{sec}$ の速度に なるので，この時の力に充分耐えること。（但し，ク ライオスタットその他全体はバネで充分, 力を緩和さ れる。)

上記の使用条件の中で(5)の重さの制限が一番きびし く,この点が設計の第一歩となった。カリフォルニア 大学の場合は鞍型コイルを二つ向き合せた方式をとっ たが, 筆者等の案では, 電磁力, 磁界分布, クライオ スタットの各問題点から考えて，ソレノイド形式を選 んだ。ソレノイド形式をとるにしても，二つのソレ， イドにするか，一つのソレノイドにするかは以下に述 ベるように検討を進めた。

二つのソレノイドにすると放電箱は当然この二つの ソレノイドの中に入り磁界利用の点から理想的である が,電磁力を支えるための充分な構造物が必要である。 また, この構造物の間は諸々の光学装置, 宇宙線の入 口等の点からできるだけ室温の利用空間にしなければ ならないので，熱絶縁の構造が複雑になる。一方，一 つのソレノイドにすると, 電磁力に対する問題は全く 無くなり，液体へリウムの補給，デュワーの機構の点 からみても楽になるが，放電箱はソレノイドの側面に 接して設置されるので, 磁界の点からは発生する磁界 を充分に利用できず,必ずしもよい方法とはいえない。 このように，それぞれの方法に長所，短所があるの で，一応入射角 $60^{\circ}$ 及び $80^{\circ}$ の二つのソレノイドの方 式と，一つのソレノイド方式の三つを検討した。二つ のソレノイドによる実験装置の配置は第 1 図に示す様 なものとなる。

\section{3. 電磁石の寸法と磁界分布}

きまった重さで所要の磁界の発生ができるかどうか は次の方法によった。二つのソレノイドの場合, ソレ ノイドの間の距離Lをきめる。ソレノイドの長さ $l$, 内半径 $\mathrm{a}_{1}$, 外半径 $\mathrm{a}_{2}$ とすると, 電線の占める体積 $\mathrm{V}$ は二つのソレノイドにたいし，

$$
V=2 l \pi\left(a_{2}{ }^{2}-a_{1}{ }^{2}\right)
$$

となる。後に述心゙るように，アルミニウム安定化導線 を用いる可能性もあるが，一応銅安定化線を想定して 設計を進めると，比重を 0.8 (全平均) とし, 重さは $\mathrm{M}=0.8 \mathrm{~V}$ であたえられる。一方, 二つのソレノイド による中心磁界は，
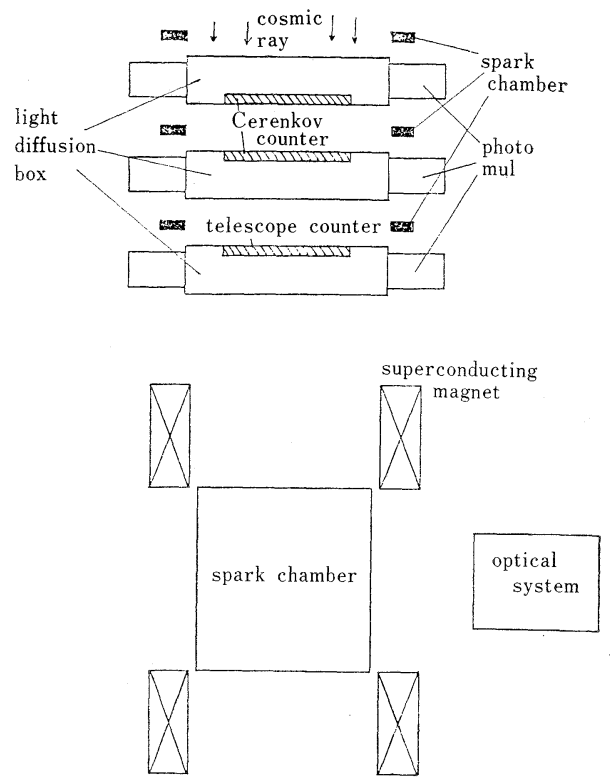

Fig. 1 宇宙線測定装置

$$
\begin{aligned}
B_{2}= & u_{0} j\left\{\left(\frac{L}{2}+l\right) \ln \frac{a_{2}+\sqrt{a_{2}^{2}+(L / 2+l)^{2}}}{a_{1}+\sqrt{a_{1}^{2}+(L / 2+l)^{2}}}\right. \\
& \left.-\frac{L}{2} \ln \frac{a_{2}+\sqrt{a_{2}^{2}+(L / 2)^{2}}}{a_{1}+\sqrt{a_{1}^{2}+(L / 2)^{2}}}\right\} \quad(2)
\end{aligned}
$$

であたえられる。(式中の単位系はす心゙て MKS 以下 同様）したがって，コイルの重さをめると，体積の式 (1)より $a_{1}, a_{2}, l$ の中一変数少くなるので, $B_{\mathrm{Z}}$ は $a_{1}, a_{2}$ の二変数の式となる。 $a_{1}$ を変数, $a_{2}$ をパラメ 一タとして, 電流密度 $j$ は degradation の可能性を 含み $10^{4} \mathrm{~A} / \mathrm{cm}^{2}$ とし， $B_{\mathrm{z}}$ の最大值を求めることを行 った。

一つのソレノイドの場合，Zをソレノイドの中心点 からみた放電箱の中心の点とすると, その点の磁界は よく知られた式

$$
\begin{aligned}
B_{\mathrm{z}}= & \frac{u_{0} j}{2}\left\{\left(\frac{l}{2}-z\right) \ln \frac{a_{2}+\sqrt{a_{2}^{2}+(l / 2 Z-)^{2}}}{a_{1}+\sqrt{a_{1}^{2}+(l / 2-Z)^{2}}}\right. \\
& \left.+\left(\frac{l}{2}+z\right) \ln \frac{a_{2}+\sqrt{a_{2}^{2}+(l / 2+Z)^{2}}}{a_{1}+\sqrt{a_{1}^{2}+(l / 2+Z)^{2}}}\right\}
\end{aligned}
$$

によってあたえられ，二つのソレノイドの場合と同様 の方法で $B z$ の最大值をもとめる。

ソレノイドの寸法及び位置がきまると磁界分布をも とめる。一つのソレノイドの任意の点 $(r, z)$ の磁界 はつぎの式であたえられる。ソレノイドの長さの座標 は $\zeta_{1}, \zeta_{2}$, 半径は $\rho_{1}, \rho_{2}$ で示すと, 


$$
\begin{aligned}
& B z=\frac{j \mu_{0}}{4 \pi} \int_{\zeta_{1}}^{\zeta_{2}} \int_{\rho 1}^{\rho_{2}} \int_{0}^{2 \pi} \\
& \frac{(\rho-r \cos \phi) \rho d \phi d \rho d \zeta}{\left[(z-\zeta)^{2}+\rho^{2}-2 \rho r \cos \phi+r^{2}\right]^{3 / 2}} \\
& =-\frac{\pi_{0 . j} z}{4 \pi} \int_{0}^{2 \pi}\{\ln [(\rho-r \cos \phi) \\
& \left.+\sqrt{Z^{2}+r^{2}+\rho^{2}-2 \rho r \cos \phi}\right]+\frac{1}{2} \frac{r \cos \phi}{Z} \\
& \ln \frac{\sqrt{Z^{2}+r^{2}+\rho^{2}-2 \rho r \cos \phi}-|Z|}{\sqrt{Z^{2}+r^{2}+\rho^{2}-2 \rho r \cos \phi}+|Z|} \\
& -\frac{r \sin \phi}{|Z|} \tan ^{-1} \\
& \left.\frac{|Z|(\rho-r \cos \phi)}{r \sin \phi \sqrt{z^{2}+r^{2}+\rho^{2}-2 \rho r \cos \phi}}\right\} \\
& \left.\left.d \phi\right|_{z_{1}} ^{z_{2}}\right|_{\rho_{1}} ^{\rho_{2}} \\
& B_{r}=\frac{j \mu_{0}}{4 \pi} \int_{\zeta_{1}}^{\zeta_{2}} \int_{\rho_{1}}^{\rho_{2}} \int_{0}^{2 \pi} \\
& \frac{(z-\zeta) \rho \cos \phi d \phi d \rho d \zeta}{\left[(z-\zeta)^{2}+\rho^{2}-2 \rho r \cos \phi+r^{2}\right]^{3 / 2}} \\
& =\frac{j \mu_{0}}{4 \pi} \int_{0}^{2 \pi}\left\{\cos \phi \sqrt{Z^{2}+\rho^{2}+r^{2}-2 \rho r \cos \phi}\right. \\
& +r \cos ^{2} \phi \ln [(\rho-r \cos \phi) \\
& \left.\left.+\sqrt{Z^{2}+\rho^{2}+r^{2}-2 \rho r \cos \phi}\right]\right\} d \phi\left|\begin{array}{l}
Z_{2} \\
Z_{1}
\end{array}\right|_{\rho_{1}}^{\rho_{2}}
\end{aligned}
$$

レノイドの系を No. 1，一つのソレノイドの系をNo. 2,80 度の入射角度の入射角を持った二つのソレノイ ドの系をNo. 3 と呼ぶと, それぞれの寸法, 磁界は 第 1 表に, ソレノイドの配置及び磁界分布は第 2 図 第 8 図に示すものである。これらの図表を検討した結 果，それぞれの問題は次のようなものとなった。No. 1 は大射角がクライオスタットに取りつけると 50 度し かとれない。

No. 2 はソレノイドに接して放電箱を設置するとし ても，放電箱中で所要の磁界を得るためにはソレノイ ド中の最大磁界が非常に大きくなり，超電導線の特性 からみて限界に近い值となる。

No. 3 注入射角は大きくとれるが，中心磁界がNo. 第 1 表 三つの案の電磁石の特性（重さは 銅安定化線を想定したもの)

No. 1 No. 2 No. 3

ソレノイドの長さ

$5.0 \mathrm{~cm} \quad 13.0 \mathrm{~cm}$

$11.5 \mathrm{~cm}$

ソレノイドの内径

$24.0 \mathrm{~cm} \quad 24.0 \mathrm{~cm}$

$20.0 \mathrm{~cm}$

"

の外径

$50.0 \mathrm{~cm}$

$50.0 \mathrm{~cm}$

$35.0 \mathrm{~cm}$

ソレノイド間の距離

$30.0 \mathrm{~cm}$

$30.0 \mathrm{~cm}$

\section{超電導線の重量}

$120 \mathrm{~kg} \quad 160 \mathrm{~kg} \quad 120 \mathrm{~kg}$

中心磁界 (放電箱)

$16.4 \mathrm{kG}$

$17.0 \mathrm{kG}$

$11.8 \mathrm{kG}$

最大磁界

$42.4 \mathrm{kG} \quad 78.0 \mathrm{kG} \quad 51.4 \mathrm{kG}$

となる。ただし， $Z_{1}=z-\zeta_{1}, Z_{2}=z$ 一らである。二つのソレノイドの場 合はいらまでもなく,ソレノイドの 座標をきめて，上式のそれぞれのソ レノノドによる和を取ればよい。

二つのソレノイドの場合は， $L=$ $30 \mathrm{~cm}$ として (2) 式による最適条件 の解析を括こない, ソレノイドの寸 法をきめた。銅安定化線を想定する と, 二つのソレノイドの場合は, 線 の重さ $120 \mathrm{~kg}$, 一つのソレノイドの 場合は線の重さ $160 \mathrm{~kg}$ とした。300 $\mathrm{kg}$ の内残された量がクライオスタ ット，巻枠にあてられる。ソレノイ ドの内径は放電箱の方からみても余 り選択度は大きくないが，(2) 式 の最適条件もきびしいものでなく， $a_{1}, a_{2}$ の数 $\mathrm{cm}$ の変化によって大 きく変るものではない。一つのソレ ノイドについても同様の解析を行っ た。60度の入射角をもった二つのソ

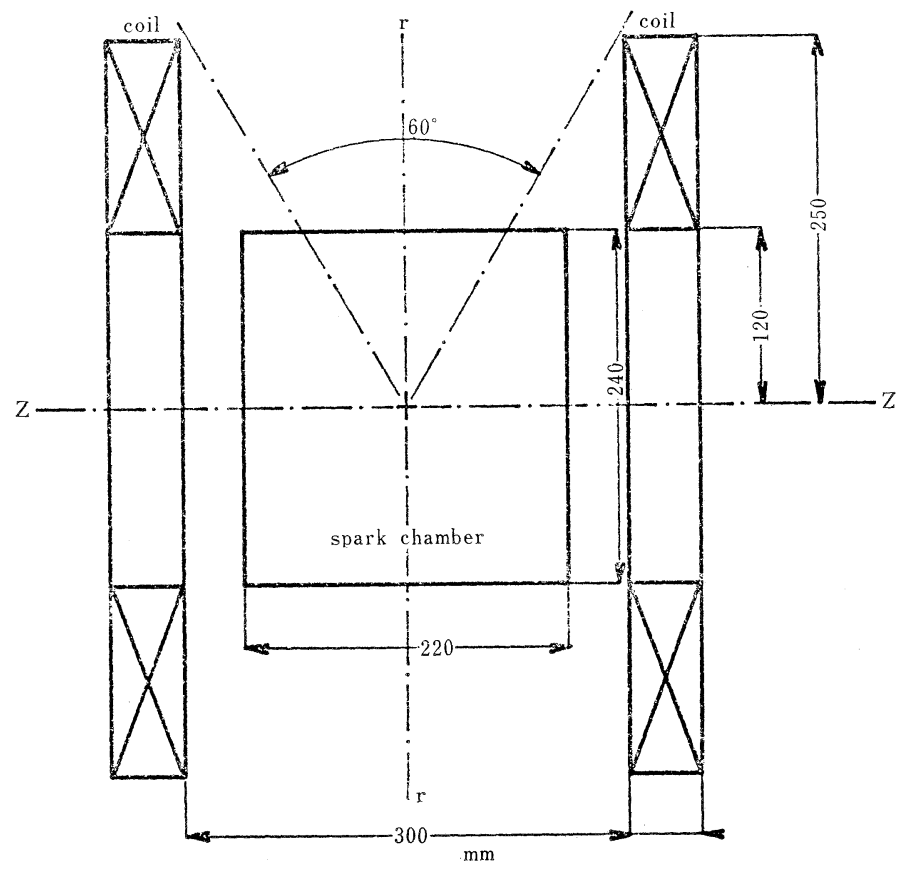

Fig. 2 第 1 案 (No. 1) の電磁石

Vol. 5 No. 5 (1970) 
1 より低下し，それに反して最大磁界が No. 1 より あがり, degradation の問題からみた場合 No. 1 上 り不利である。上記の考察から，入射角に譲歩をあた え，No.1 の系をここで取りあげた。(4)，(5)式よ り No.1による磁界をもとめ, 等磁界強度線及び磁力 線の分布をもとめた。結果を第 9 図に示す。

No. 1 の方式に扔いて，一つのソレノイドによる他

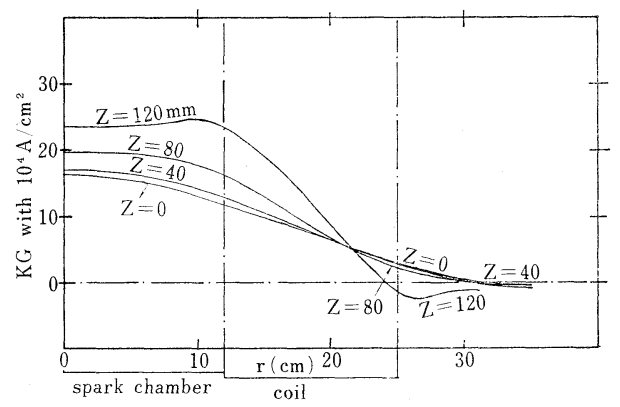

Fig. 3 No. 1 電磁石の $\mathrm{Bz}$ の分布

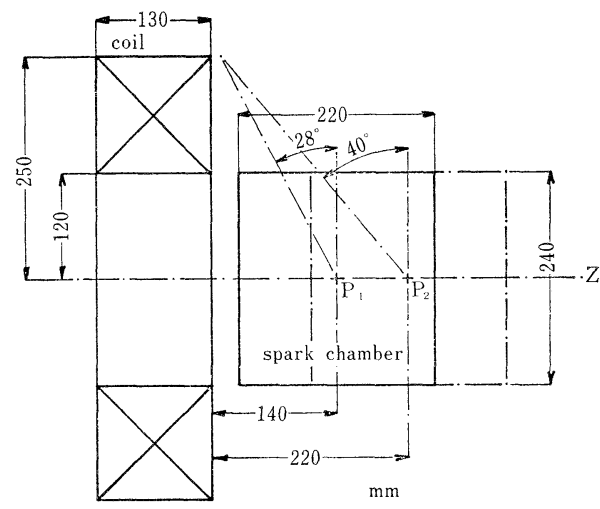

Fig. 4 第 2 案 (No. 2) の電磁石, $\mathrm{P}_{1}, \mathrm{P}_{2}$ はそれぞれの角度に対する放電箱の 中心点を示寸

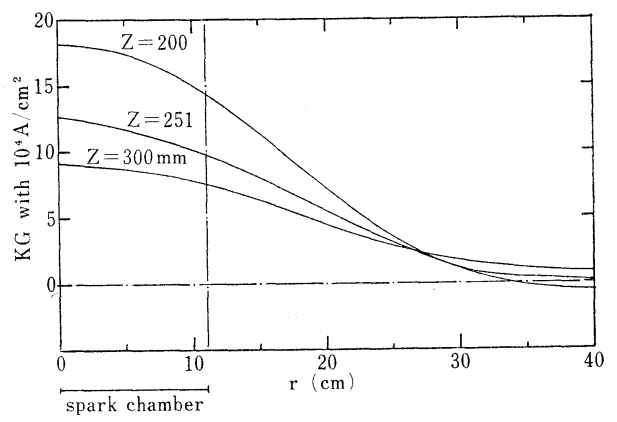

Fig. 5 No. 2 電磁石の $\mathrm{Bz}$ の分布
のソレノイドが受ける電磁力は, $10^{4} \mathrm{~A} / \mathrm{cm}^{2}$ を想定す ると内側で $4 \mathrm{~kg} / \mathrm{cm}^{2}$, 外側で $5 \mathrm{~kg} / \mathrm{cm}^{2}$ となり，もら一 方の対称の部分を考光ると引力はそれぞれ $8 \mathrm{~kg} / \mathrm{cm}^{2}$ $10 \mathrm{~kg} / \mathrm{cm}^{2}$ となる。全面に加わる引力は 14.2 tons に なる。これを支持するためにソレノイド間に充分な構 造物が必要であるが，上記の值は $10^{4} \mathrm{~A} / \mathrm{cm}^{2}$ の想定で あるので, 臨界電流密度がこの值をうわまわった場合 の利用を考えると， 2.5 倍以上の強度が必要である。 コイル巻枠は外径に加わる電磁力が大きいことを考 え, 二つの円筒と円板の一体となったものを作り, 巻

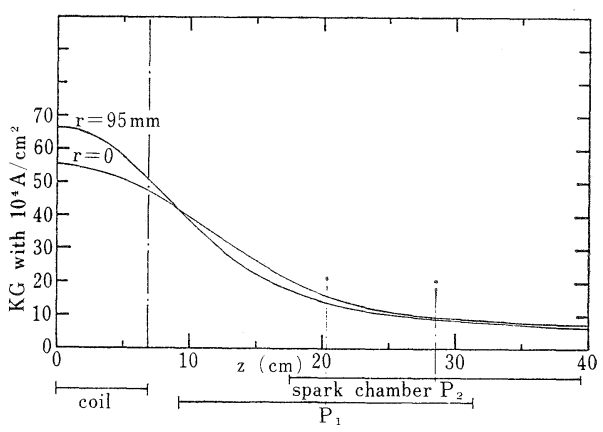

Fig. 6 No. 2 電磁石の $\mathrm{Bz}$ の分布

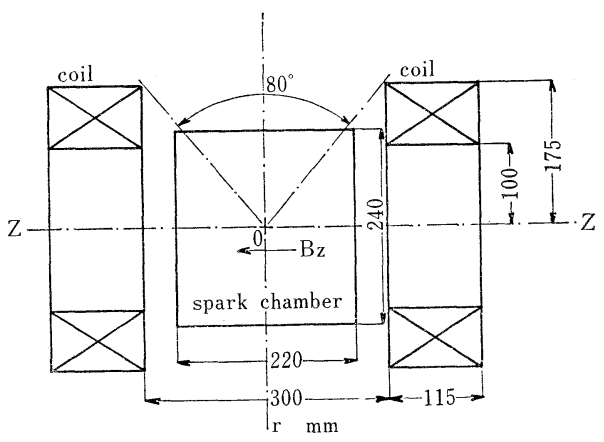

Fig. 7 第 3 案 (No. 3 ) の電磁石

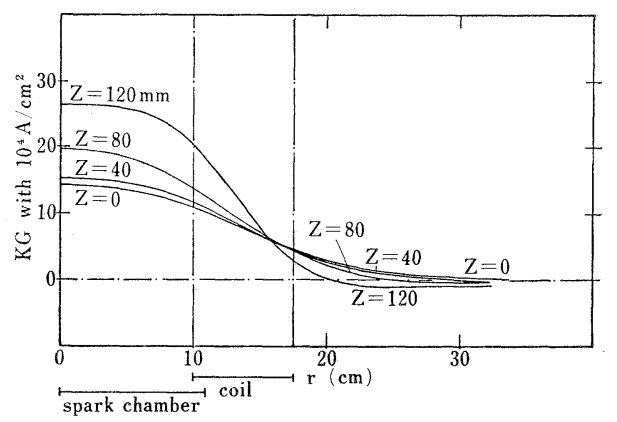

Fig. 8 No. 3 電磁石の $\mathrm{Bz}$ の分布 低温工学 
線は別途行った後この巻枠中にソレノイドをおさめ， その後もら一枚の円板で封じ込めこれを溶接してコン パクトな形にする。こうすることによって巻枠の外周 部が変形することを防ぐ。

\section{4. 超電導線の選択}

この設計にたいして考えられる超電導線には, 重さ の点を考慮してアルミニウム安定化線, もら一つの案 として degradation が殆どないといわれているフイ ラメント状超電導線が挙げられる。両者について以下 のよらに検討した。

1) アルミニウム安定化線

CGE (Compagnie Générale d' Electricité) から 製作，市販されているアルミニウム安定化線について 検討を進めた。これは Supercon T 48 B 0.013”ゆの 超電導線 6 本と同径のステンレス線 1 本を中心に然り 合せた上にアルミニウムを被覆し, 表面に陽極酸素を 施しさらにエボキシ系絶縁材で絶縁された直径 1.41 $\mathrm{mm}$ の線である。この線については筆者等が既に種々
の条件下で minimum propagating current の実験 を行っている2)。本目的の基礎実験として，内径 56.0 $\mathrm{mm}$, 外径 $90.5 \mathrm{~mm}$, 長さ $198.0 \mathrm{~mm}$ のソレノイドを つくりこれを他のソレノイドの中に入れてその特性を 調へた。第10図に minimum propagating current の結果とともにこの結果を示す。電流固定, 外部磁界 掃引の臨界值と, その逆の場合の臨界值には著しい差 はみられず,これらの結果は Supercon T48 B の 臨界值 ${ }^{3)}$ とも殆ど一致している。図中に示した本電磁 石の動作線は充分に超電状態の領域に入っている。一 方重さの点からみても比重は線のみで $4 \mathrm{~g} / \mathrm{cc}$ であり 巻線の占積率を考えると更に下る。この值は次に述心 る銅安定化線の密度の約半分であり, 気球に掛る負担 を少くしたり或はその分クライオスタットの強度を増 加させることができる。上記の結果からこの超電導線 をわれわれの目的の電磁石に利用することは可能であ りここれ用いることにより電線自体の重さを減軽す るといら特徴がある。

2) フィラメント状銅安定化線

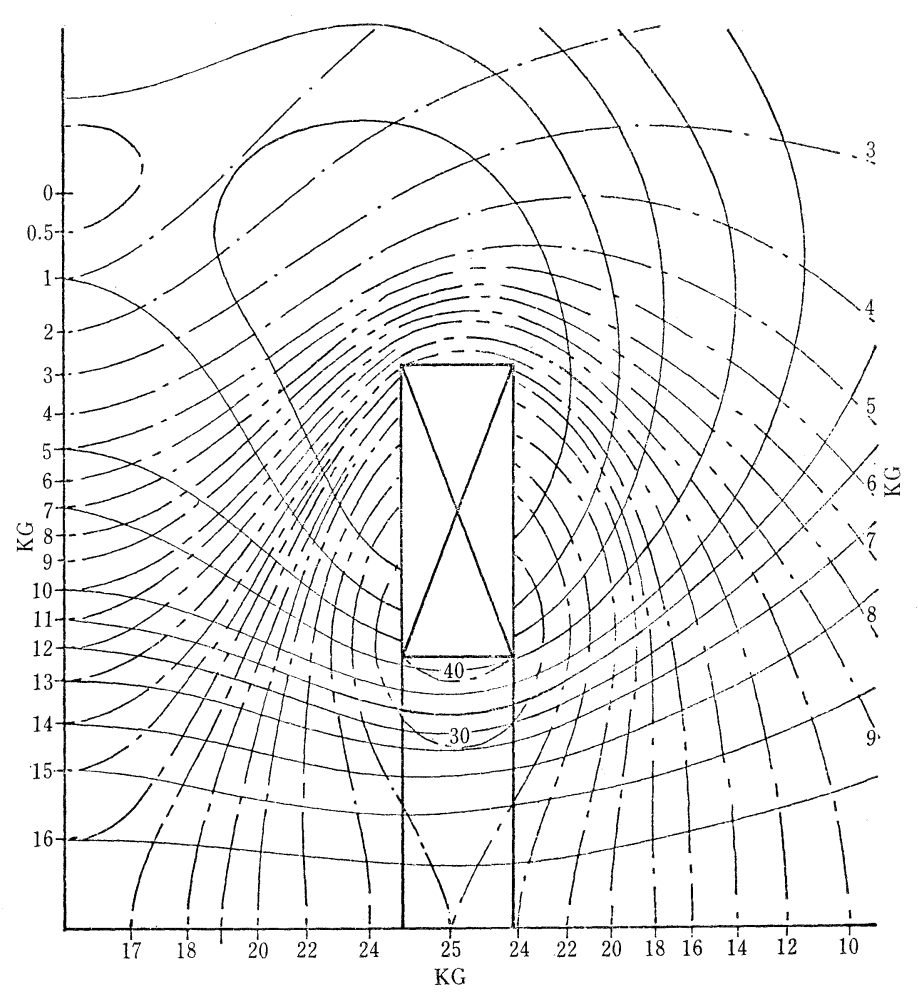

Fig. 9 No. 1 電磁石の磁束分布（実線）と等磁束密度分布 (一点鎖線)

Vol. 5 No. $5(1970)$ 
IMI と AIRCO の夫々のフイラメント状銅安定化 線を考える。IMI のC 361 は銅と超電導材の比が 2: 1 で, $44 \mathrm{kG}$ に於て全平均電流密度 $6 \times 10^{4} \mathrm{~A} / \mathrm{cm}^{2}$ が 得られることが報告されている4)。一方, Argonne 研 究所に㧍ける, 銅と超電導の比が $3: 1$ のIRCO の 電線を用いた 56 Kjoule のソレノイドの実験では全 平均電流密度 $1.7 \times 10^{4} \mathrm{~A} / \mathrm{cm}^{2}$ が得られている5 。こ の值は短線の特性と殆ど同じ值とみてよい6)。われわ れのソレノイドのエネルギー，設計のスタートの $10^{4}$ $\mathrm{A} / \mathrm{cm}^{2}$ の電流密度を考慮すると AIRCO の電線で充 分であり，かつ quenching の場合を考えると銅の量 が多いことが好ましい。第11図は AIRCO の短線の特 性と, われわれの電磁石の動作特性を比較して示すも ので，動作点は充分に余裕を取ってある。第 2 表に は $\mathrm{CGE}$ とAIRCOの導線の性較を比較して示した。
第 2 表 CGE と AIRCO の超電導線の特性 Alustable (CGE)

外径

$1.41 \mathrm{~mm} \phi$

超電 導線

$0.33 \mathrm{~mm} \phi$ (銅被覆) $\times 6$

絶縁

陽極酸化 + エポキシ

単位長価格 $¥ 1,200 / \mathrm{m}$

KRYOCONDUCTOR (AlRCO)

銅と超電導線との比 $3: 1$

超電 導線

$30 \mu$

超電導線の数 361

絶縁された導体の寸法（正方断面）

絶縁

$1.2 \mathrm{~mm} \times 1.2 \mathrm{~mm}$

絶縁材の厚さ

オルマル

然りのピッチ

$20 \mu$

単位長価格

$¥ 600 / \mathrm{m}$

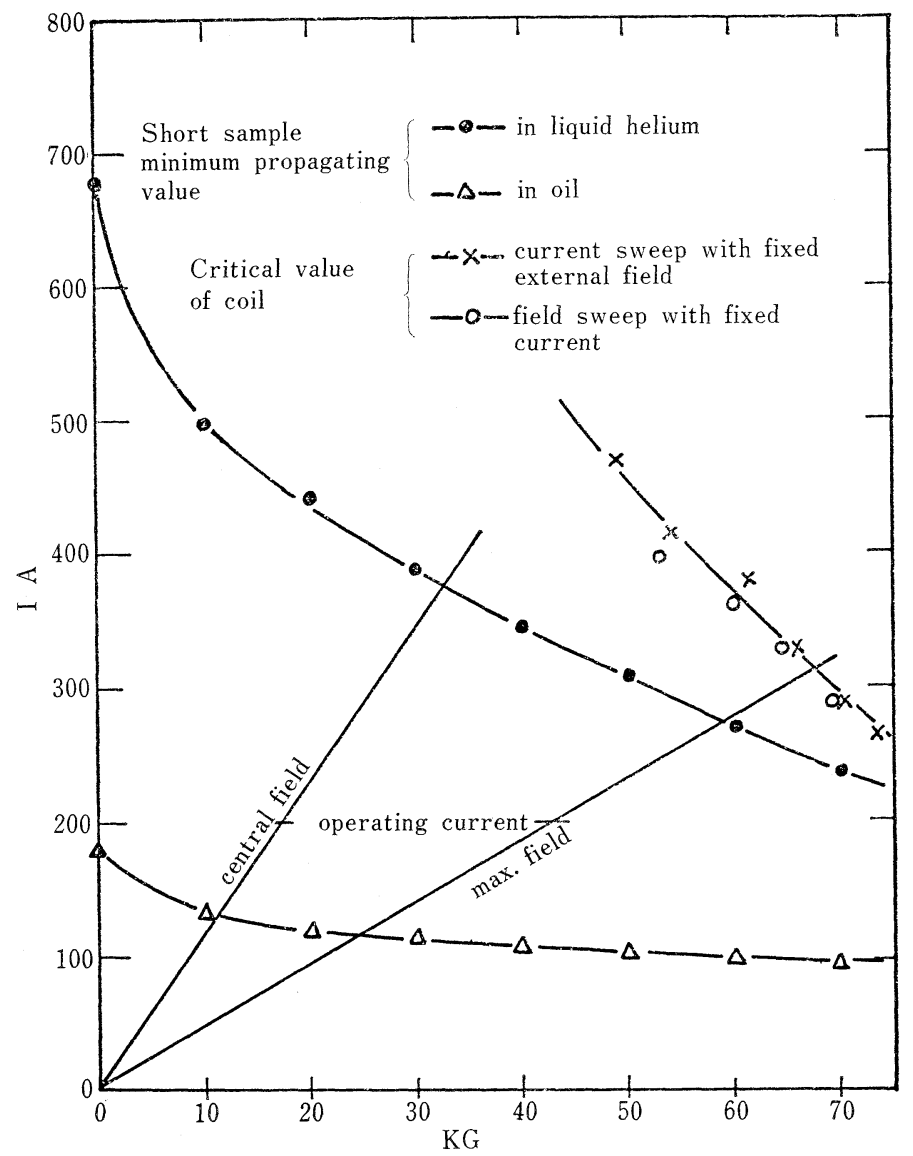

Fig. 10 CGE. Alustable の諸条件による minimum propagating current と Coil の臨界值及び No. 1 電磁石の動作線 


\section{5. クライオスタット}

この電磁石の巻枠はへリウム容器をかねる。この方 法は既にサックレーで偏極ターゲットの超電導電磁石 で成功している7)。もう一つの本装置の特徴はへリウ ムの補給タンクがあり単に液の補給をしているという ことである。理想的には補給タンクなしで巻枠である 容器が縦方向に充分長く，これに充したへリウムが時

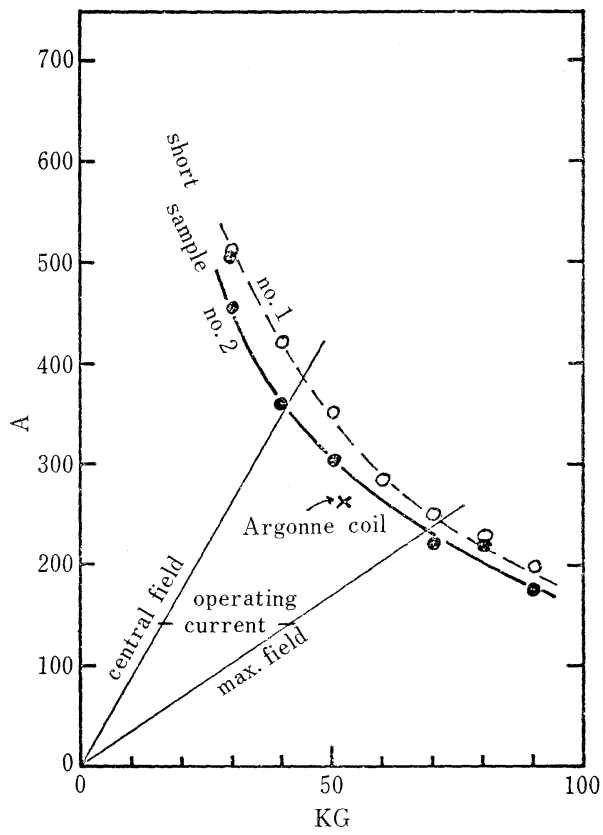

Fig. 11 AlRCO. filamentary superconducting uire $の$ shot sample $の$ 臨界值 と No. 1 電磁石の動作線
間内持続するのがよい。しかし，この方法ではセレン コフ・カウンター等の設置ができなくなる。したがっ て，第12図に示すように，電磁石の横に補給タンクを 設置し，電磁石とは下部のパイプでつなぎ，液面を一 定とするために，この内圧によって下部から補給する 方法をとる。二つのソレノイドは電気的に直列につな がれ，その連結は電磁力を支持するパイプの中におさ め，この支持棒の中にも液体へリウムが入るようにす る。電流供給の導線は, 充電の時のみ用い永久電流状 態ではその後はずし外部に引きぬけるよらにする。電 磁石放電のための抵抗は重さのためからできるだけ用

第 3 表 No. 1 電磁石の特性の詳細 巻線の内半径

$12 \mathrm{~cm}$

巻線の外半径

$25 \mathrm{~cm}$

1 ソレノイドの長さ $5 \mathrm{~cm}$ ソレノイド間の距離 $30 \mathrm{~cm}$ 絶縁電線の寸法 $0.120 \mathrm{~cm}$ (正方形) 総電線長

$11,000 \mathrm{~m}$

(銅安定化線 KRYOCONDUCOTR) 全ターン数 9,000

重量（超電導線のみ）

$120 \mathrm{~kg}$ (銅安定化線)

定格電流值

$150 \mathrm{~A}$

(KRYOCONDUCTOR)

定格平均電流密度 $10,000 \mathrm{~A} / \mathrm{cm}^{2}$

エネルギー(於電格電流值) $175 \mathrm{KJ}$

アンペア・ターン

$1.3 \times 10^{6} \mathrm{AT}$

中心磁界

$16.4 \mathrm{KG}$

導体上最大磁界

$42.4 \mathrm{KG}$

インダクタンス

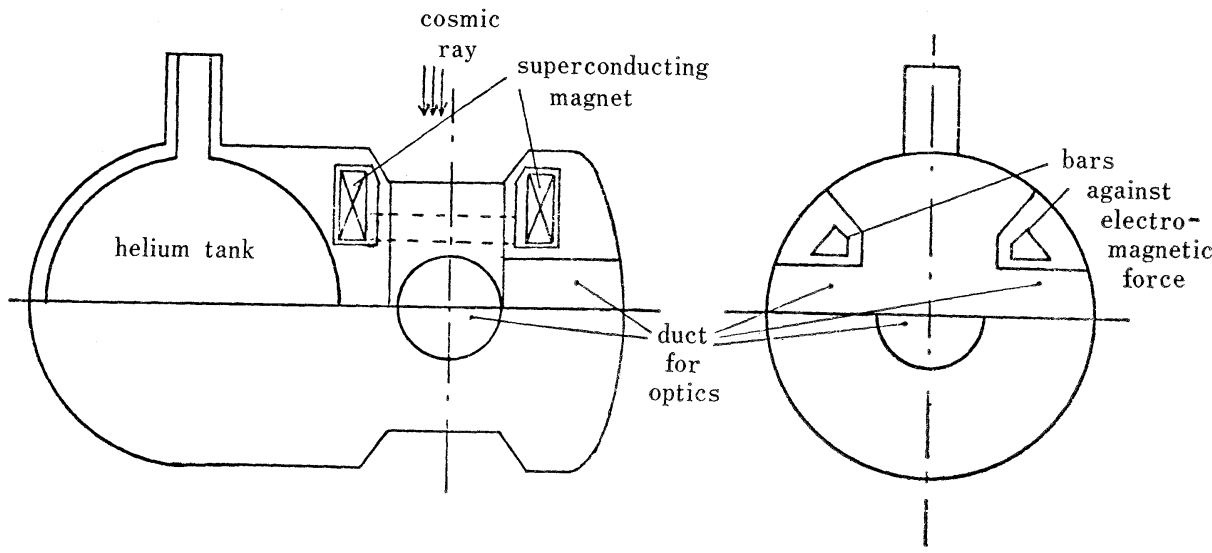

Fig. 12 No. 1 電磁石用クライオスタット系

Vol. 5 No. 5 (1970) 
第 4 表 No. 1 電磁石とカリフォルニア大 宇宙線用電磁石

$$
\text { カリフォルニア大 サックレー }
$$

$\begin{array}{llc}\text { 中心磁界 } & 11 \mathrm{KG} & 17 \mathrm{KG} \\ \text { 形 式 } & \text { 鞍型 } & \text { ソレノイド } \\ \text { 利用空間直径 } & 1.0 \mathrm{~m} & 22 \mathrm{~cm}\end{array}$

導体 $0.51 \mathrm{~mm} \phi \mathrm{Nb} \mathrm{Ti} 3$ 本 フィラメント状 16本の銅の撚線 $\mathrm{Nb}-\mathrm{Ti}$

電 流 $870 \mathrm{~A} \quad 150 \mathrm{~A}$

インダクタンス $\quad 3.9 \mathrm{H} \quad 13 \mathrm{H}$

エネルギー $1.2 \times 10^{6} \mathrm{~J} \quad 1.3 \times 10^{6} \mathrm{~J}$

重さ(全部含) $\quad 1,630 \mathrm{~kg}$

$\begin{array}{lcc}\text { コイル枠 } & 330 & 60 \\ \text { ヘリウム容器 } & 135 & 20 \\ \text { 超電導線 } & 500 & 120 \\ & & \left(\begin{array}{c}\text { 銅安定線) } \\ 60 \\ \end{array}\right. \\ & & \left(\begin{array}{c}\text { アルミニウ } \\ \text { ム安定線 }\end{array}\right) \\ \text { 構造支持 } & 280 & 10 \\ \text { デュワー本体 } & 385 & 30 \\ \text { 用時間 (全) } & 48 \text { 時間 } & 12 \text { 時間 }\end{array}$

いないようにし，永久電流スイッチ或は電磁石自体の 帯電導の抵抗值で放電できるよう工夫する。この点に つマては充分な基礎実験を行う予定である。

電磁石の重さは第12図の右側のコイルについては上 部から二つの支持棒で, 左側のコイルについては左側 のクライオスタットの首で支持する。電磁石の重さ及 び電磁力以外に加わる力としては, 気球の落下の時, $4.5 \mathrm{~m} / \mathrm{esc}$ の速度を持っているので, 全体の支持枠か
ら充分なバネでこの系統を支持する。このことは他の 光学系やカウンター系も同様の条件が要求されるの で，全体として充分安全な範囲にまとめる。結局，予 備タンクのヘリウムの量は $80 l$ とし，クライオスタッ トの厚みは $1 \mathrm{~mm}$ のステンレスを用い，デュワー本体 及びーリウム容器等で $50 \mathrm{~kg}$ ，コイル枠は $60 \mathrm{~kg}$ とな る。最終的には電磁石の特特性は第 4 表の上うにな る。参考にカリフォルニア大学で製作したものの諸特 性を列記した。

\section{謝 辞}

この設計を進めるにあたって，参考意見，討論を進 めていただいたChef de Groupe の Monsienr Tsai に感謝致します。また，日本語で発表を許可して下さ った, Chef de Service の Monsienr Prugne に御 礼申し上げます。

\section{参考文 献}

1) C.E. Taylor et a1: Proceedings International Conference on Magnet Technology, p. 617 (1967) Oxford.

2) S.Shimamoto and H.Desportes, to be published in JAP July 1970.

3) Supercon Division: Catalogue 1967 T 48 B

4) IMI : Catalogue, Mey 1970.

5) H.Desportes : private commuincation

6) AIRCO : private commuincation

7) H.Desportes : Proceedings International Conference on Magnet Techogy, p. 603 (1967) Oxford. 